\title{
Study of the viticultural technical itineraries carbon footprint at fine scale
}

\author{
E. Adoir ${ }^{1}$, S. Penavayre ${ }^{1}$, T. Petitjean ${ }^{2}$, and L. De Rességuier ${ }^{2}$ \\ ${ }^{1}$ Institut Français de la Vigne et du Vin (IFV), Pôle Bourgogne-Beaujolais-Jura-Savoie, 69661 Villefranche/Saône, France \\ ${ }^{2}$ EGFV, Bordeaux Science Agro, INRA, Université Bordeaux, ISVV, 33883 Villenave d'Ornon, France
}

\begin{abstract}
Viticulture faces two challenges regarding climate change: adapting and mitigating greenhouse gas emissions. Are these two challenges compatible? This is one of the questions to which Adviclim project (Life project, 2014-2019) provided tools and answers. The assessment of greenhouse gas emissions was implemented at the scale of the plot using a life cycle approach: calculating the carbon footprint. This approach makes it possible to take into account the emissions generated during each stage of the life cycle of a product or a service: in this case, the cultivation of one hectare of vine for one year. Carbon footprint was assessed for the 5 pilot sites of the Adviclim project: Saint-Emilion (France), Coteaux du Layon/Samur (France), Geisenheim (Germany), Cotnari (Romania) and Plompton (United Kingdom). An important work for primary data collection regarding observed practices was carried out with a sample of reresentative farms for these 5 sites, and for one to three vintages depending on the site. Beyond the question asked in the project, the calculation of these carbon footprints made it possible to (i) make winegrowers aware of the life cycle approach and the share of direct emissions generated by viticulture, (ii) acquire new references on the technical itineraries and their associated emissions, (iii) improve the adaptation of the methodology for calculating the carbon footprint to viticulture.
\end{abstract}

\section{Introduction}

The phenomenon of climate change puts viticulture face two challenges: adapt but also mitigate its effects on climate change. Are these two challenges compatible? Do practices and itineraries for adapting viticulture to this new context also make it possible to reduce greenhouse gas (GHG) emissions from viticulture? This is one of the questions that the LIFE-ADVICLIM project has provided tools and answers.

In response to these challenges, recognising the need to assess climate and its impact on viticulture at the vineyard scale, the LIFE-ADVICLIM project aims to study climate change adaptation scenarios for a range of vineyards which represent the climatic diversity of European wine regions. The LIFE-ADVICLIM project develops climate change adaptation strategies which can be adapted to European wine regions, assess their impact on climate change and demonstrate their application at the vineyard scale. The project's measurement network and web platform enable wine producers to assess the impacts of climate change on their plots, simulate adaptation scenarios, and measure the GHG emissions related to their practices. These technologies have been tested on demonstration sites in five European vineyards regions: Cotnari, Rheingau, Bordeaux, Sussex and Val de Loire, thanks to funding from the European Life programme.

The aim of Adviclim action B2 is to assess the carbon footprints of technical itineraries for the five project pilot sites. The objectives of doing this assessment are to:

- identify the main processes responsible for GHG emissions and to characterize some interventions frequently producing high GHG emissions for each pilot site;

- identify the proportion of indirect emissions against the proportion of direct emissions from the plot, on which the vine-growers can make modifications;

- compare GHG emissions of observed practices against the practices modelled in scenarios;

- extrapolate, if possible, the emissions produced by sampled plots to the pilot site scale according to plots representativity.

\section{Materials and method}

\subsection{Outlines of the study}

\subsubsection{Approach, perimeter and functional unit}

The approach to calculate the carbon footprint of a viticultural activity is a life cycle approach. It takes into account all the life cycle steps of a product in the GHG flows inventory, from resources extraction and energy production for inputs manufacturing to their end of life (cf. Fig. 1). This approach implies to define the studied object, system, perimeter and the functional unit of the study, in accordance with its objectives.

- Studied object: a plot planted with vine.

- Studied system: all the elements involved in the activities of the studied object (tools, inputs, equipments, staff).

- Boundaries of the study: all the direct emissions produced by the activities linked to the technical itinerary (use of tools, functioning of equipments, 


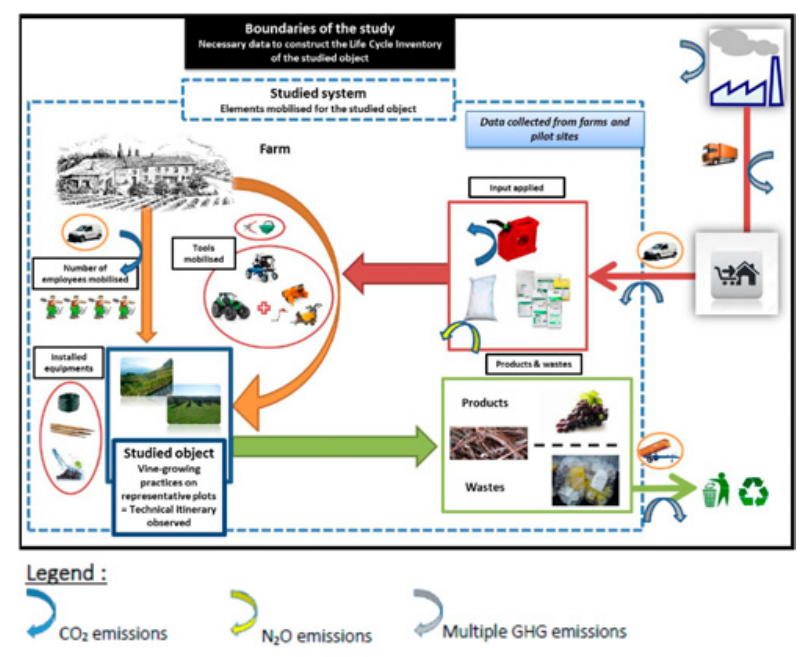

Figure 1. Life cycle of the cultivation of a plot planted with wine.

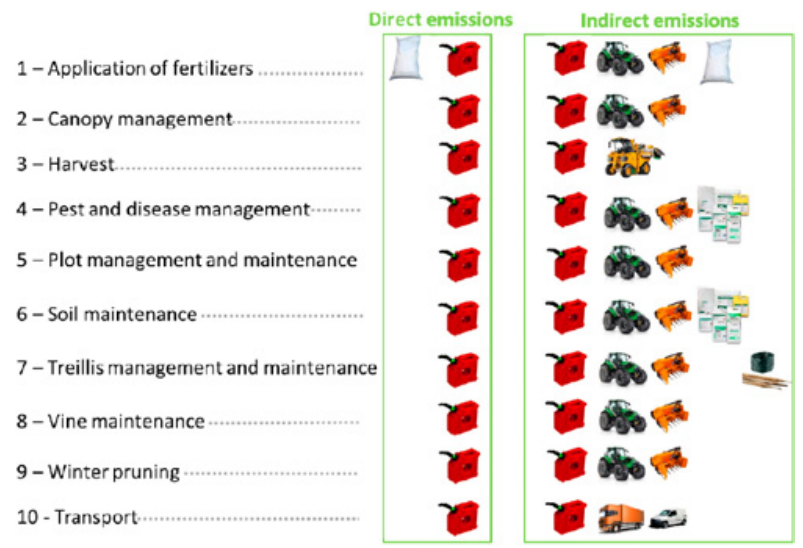

Figure 2. Elements taken into account in the GHG balance sheets of vineyard plots. Classification by interventions and type of emissions.

transport between the farm and the plot), and all the indirect emissions produced by manufacturing, transporting and dealing with the end of life of the elements of the studied system. Those two types of emissions are drawn on the Fig. 1. The boundaries include only the production of grape and its transport back to the farm. The transformation into wine, the conditioning and distribution of wine are out of the scope of this study.

- Functional unit: GHG emissions are calculated for 1 ha of planted vine and 1 year.

\subsubsection{Results scale}

The scale for presenting GHG emissions budgets was set at an intermediate level of detail. The budgets for each suboperation are indeed grouped by vineyard operations, 10 in total (cf. Fig. 2). This way of aggregation helps to meet the first aim of the study (i.e. identify the main processes responsible for GHG emissions and to characterize some interventions frequently producing high GHG emissions for each pilot site).

Then, for each vineyard operation, the distinction is made between:

- the direct emissions: this includes $\mathrm{CO} 2$ emissions linked to carbon cycle and directly emitted on the plot;
Table 1. GWP values for $\mathrm{CO} 2$ and $\mathrm{N} 2 \mathrm{O}$ and several assessment methods.

\begin{tabular}{|c|c|c|}
\hline & $\mathbf{C O}_{\mathbf{2}}$ & $\mathbf{N}_{\mathbf{2}} \mathbf{O}$ \\
\hline IMPACT [3] & 1 & 156 \\
\hline Europe RECIPE [4] & 1 & 298 \\
\hline IPCC 2013 100 years [5] & 1 & 265 \\
\hline Unit & $\mathrm{kg} \mathrm{CO}_{2} \mathrm{eq} / \mathrm{kg}$ & $\mathrm{kg} \mathrm{CO}_{2} \mathrm{eq} / \mathrm{kg}$ \\
\hline
\end{tabular}

- the indirect emissions: this includes the GHG emissions produced during the extraction of raw materials, the manufacturing of system elements (tools, inputs, equipments) and the transport of system elements from the manufacturer to the farm (cf. Fig. 1).

This distinction helps to meet the second aim of the study (i.e. identify the proportion of indirect emissions against the proportion of direct emissions from the plot, on which the vine-growers can make modifications).

\subsection{Life cycle inventories}

A life cycle inventory (LCI) is an inventory of all the flows coming from natural resources (water, atmospheric gas, mining resources...), and emitted to natural compartments (water, air, soil), when making a product or providing a service. Considering the amount of data needed to estimate these elementary flows according to a life cycle approach, a LCI consists in using existing data sets, which are elementary life cycle inventory for many inputs, tools, equipments or energy, available in dedicated databases such as Ecoinvent [1] or Agribalyse ${ }^{\circledR}$ [2]. They are used for indirect emissions assessment.

Activity data complete this inventory. They were either:

- collected on the farm (number of sub-operations, types of tools used, power of the engines, types and quantities of inputs applied);

- defined by default or expert when the data was difficult to obtain accurately (load rate, tool life and mass, work rate, material quantities per standard equipment).

\subsection{Impact assessment}

The Global Warming Potential (GWP) is a weighting factor that aims to aggregate the effect of all the substances contributing of global warming into one value. The unit of this indicator is "CO2 equivalent", as, by definition, the $\mathrm{CO} 2$ greenhouse effect has been set up to 1 , and the greenhouse effect of other gases relatively to the $\mathrm{CO} 2$. The GWP 100 years calculates the radiative forcing over a time horizon of 100 years, in order to take into account the different residence times of the substances in the atmosphere.

Different GWP values exist according to different assessment methods. The Table 1 summarizes the GWP of the main GHG emitted by viticulture (CO2 and $\mathrm{N} 2 \mathrm{O}$ ), for three main European and international methods. The IPCC 2013 GWP 100 years has been selected for the LIFE-ADVICLIM project, to be consistent with the French database Agribalyse ${ }^{\circledR}$. This method, built by 
Table 2. Results of the GHG emissions assessment. Plot 9.

\begin{tabular}{|c|c|c|c|c|c|c|}
\hline \multirow[b]{2}{*}{$\begin{array}{l}\text { Vineyard } \\
\text { operation }\end{array}$} & \multicolumn{2}{|c|}{ Direct emissions } & \multicolumn{2}{|c|}{ Indirect emissions } & \multicolumn{2}{|c|}{$\begin{array}{c}\text { Total of emissions for } \\
\text { the vineyard } \\
\text { operation }\end{array}$} \\
\hline & $\begin{array}{c}\begin{array}{c}\mathrm{GHG} \\
\text { emissions } \\
(\mathrm{kg} \mathrm{CO}\end{array} \\
\text { eq } / \mathrm{kg})\end{array}$ & $\begin{array}{l}\% \text { of total } \\
\text { emissions } \\
\text { of the } \\
\text { vineyard } \\
\text { operation }\end{array}$ & $\begin{array}{l}\mathrm{GHG} \\
\text { emissions } \\
(\mathrm{kg} \mathrm{CO} 2 \\
\text { eq } / \mathrm{kg})\end{array}$ & $\begin{array}{l}\% \text { of total } \\
\text { emissions } \\
\text { of the } \\
\text { vineyard } \\
\text { operation }\end{array}$ & $\begin{array}{l}\text { GHG } \\
\text { emissions } \\
(\mathrm{kg} \mathrm{CO} 2 \\
\text { eq } / \mathrm{kg})\end{array}$ & $\begin{array}{c}\% \text { of total } \\
\text { emissions } \\
\text { at plot } \\
\text { scale }\end{array}$ \\
\hline $\begin{array}{c}1- \\
\text { Application } \\
\text { of fertilizers } \\
\text { and manures } \\
\end{array}$ & 0 & $0 \%$ & 0 & $0 \%$ & 0 & $0 \%$ \\
\hline $\begin{array}{c}2 \text { - Canopy } \\
\text { management }\end{array}$ & 61 & $73 \%$ & 23 & $27 \%$ & 83 & $6 \%$ \\
\hline 3 - Harvest & 153 & $78 \%$ & 43 & $22 \%$ & 196 & $14 \%$ \\
\hline $\begin{array}{c}4 \text { - Pest and } \\
\text { disease } \\
\text { management }\end{array}$ & 170 & $50 \%$ & 168 & $50 \%$ & 339 & $23 \%$ \\
\hline $\begin{array}{c}5-\text { Plot } \\
\text { management } \\
\text { and } \\
\text { maintenance }\end{array}$ & 0 & $0 \%$ & 0 & $0 \%$ & 0 & $0 \%$ \\
\hline $\begin{array}{c}6-\text { Soil } \\
\text { maintenance }\end{array}$ & 241 & $68 \%$ & 112 & $32 \%$ & 353 & $24 \%$ \\
\hline $\begin{array}{c}7 \text { - Trellis } \\
\text { management } \\
\text { and } \\
\text { maintenance }\end{array}$ & 154 & $45 \%$ & 191 & $55 \%$ & 345 & $24 \%$ \\
\hline $\begin{array}{c}8-\text { Vine } \\
\text { maintenance }\end{array}$ & 0 & $0 \%$ & 0 & $0 \%$ & 0 & $0 \%$ \\
\hline $\begin{array}{l}9 \text { - Winter } \\
\text { pruning }\end{array}$ & 0 & $0 \%$ & 0 & $0 \%$ & 0 & $0 \%$ \\
\hline $\begin{array}{c}10- \\
\text { Transport }\end{array}$ & 104 & $81 \%$ & 24 & $19 \%$ & 129 & $9 \%$ \\
\hline $\begin{array}{l}\text { Total of } \\
\text { emissions at } \\
\text { plot scale }\end{array}$ & 883 & $61 \%$ & 561 & $39 \%$ & & \\
\hline
\end{tabular}

the Intergovernmental Panel on Climate Change (IPCC), provides characterization factors for the largest number of greenhouse gases.

\subsection{Saint-Emilion, pilot site}

Saint-Emilion is one of the pilot site of the LIFEADVICLIM project. A sample of 15 plots has been selected for the study.

All the sampled plots are planted with Merlot, and equipped with the same classic trellising. However, the plots show a good variability in terms of (i) quantity of manual work, (ii) motor power of motorized tools and (iii) inter-rows plant cover surface.

The vines of a majority of plots are grown in a conventional way, two plots are under integrated viticulture, one under organic and one under biodynamic viticulture.

The numbers of intervention days for each vineyard operation varies. The two most frequent vineyard operations are the pest and disease management, and the soil maintenance. They show some variability also, due in some extent to the type of viticulture (conventional/integrated/organic/biodynamic) for the pest and disease management mainly. But even among the conventional plots, the number of intervention days are quite variable for those two vineyard operations.

The work output (the time to execute an intervention on $1 \mathrm{ha}$ ) is roughly the same between all the plots for a given sub-operation. There are some differences for inter-rows mowing and weeding work output, due to the differences in inter-rows plant cover surface of the plots (half or all the inter-rows mowed).

\section{Results}

\subsection{Assessment of a case study: the plot 9}

The Fig. 3 illustrates the GHG emissions assessment results for the plot Saint-Emilion 9, regarding the observed technical itinerary of the plot for the growing year 2015-2016. Those results are presented in details in Table 2.

GHG emissions due to viticulture on this plot are mainly direct emissions (61\% of total emissions).

The split between direct and indirect emissions is different according to vineyard operations: the direct emissions represent $78 \%$ of the emissions linked to harvest, while they represent only $45 \%$ of the emissions linked to trellis management and maintenance. Some vineyard operations (for ex, $\mathrm{n}^{\circ} 4$ and $\mathrm{n}^{\circ}$ ) involve indeed inputs or equipments that do not produce themselves any GHG emissions directly in the field when installed or applied (for example, trellising or pesticides), but of which the manufacturing produces significant indirect emissions.

The most emitting vineyard operations, excepting trellis management and maintenance, are the soil maintenance (24\% of the total emissions) and the pest and disease management (23\%). The numerous motorized pulling tools use days for those two operations explain this result. The mechanical harvest, executed in only one day, represent also a significant part of the total emissions (14\%). On the contrary, the pruning doesn't show any 


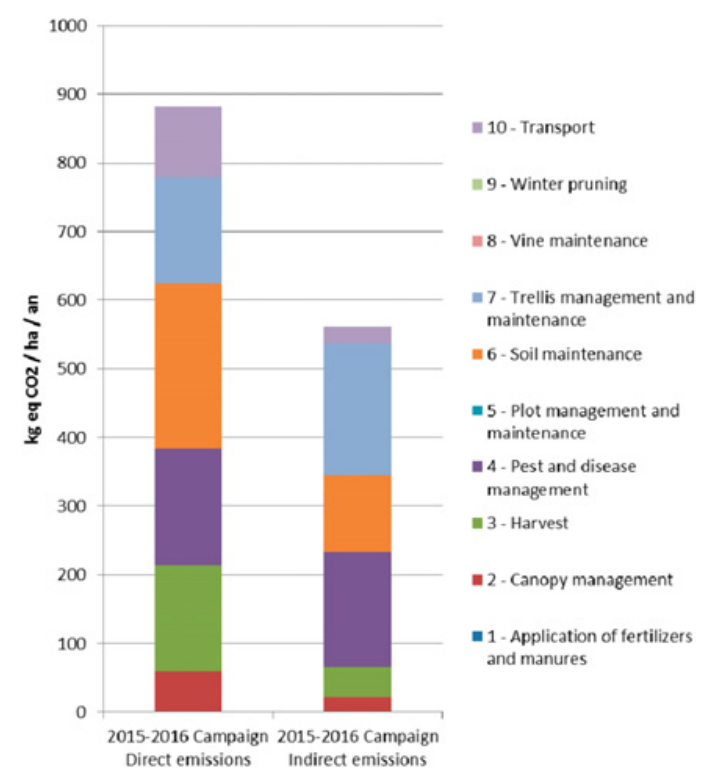

Figure 3. Results of the GHG emissions assessment. Plot 9.

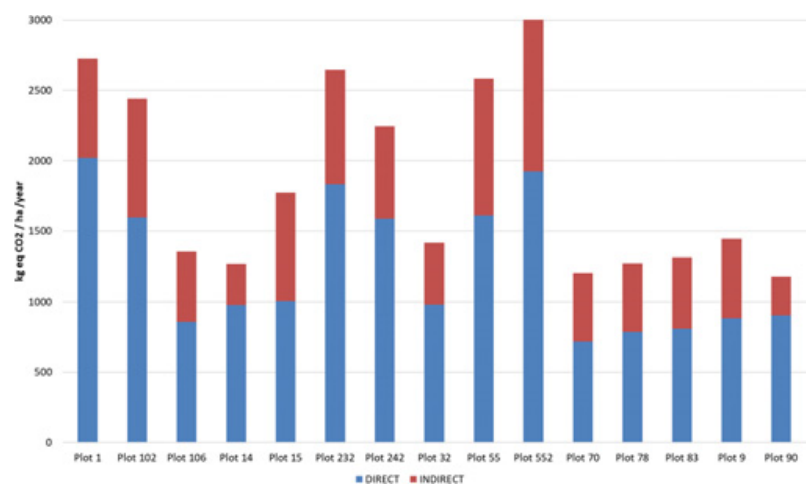

Figure 4. Results of the GHG emissions assessment for the 15 plots of Saint-Emilion (direct and indirect emissions).

GHG emissions, as it is manual interventions, and the employees' transportation is allocated to the vineyard operation "Transport".

The result of indirect emissions for the trellising equipment (13\% of the total emissions) shows the importance to take into account this kind of equipment, even after having smoothed the manufacturing emissions over the quite high lifetime (between 20 and 40 years for the material units of the trellising equipment).

\subsection{Results for Saint-Emilion pilot site}

The variability of technical itineraries appears also after the application of GHG emissions assessment method, on the Fig. 4 for the distinction between direct and indirect emissions, and on the Fig. 5 for the distinction between vineyard operations.

The total GHG balances per plot varies from single ( $1180 \mathrm{~kg}$ eq CO $2 / \mathrm{ha} /$ year for the plot 90$)$ to triple $(3000 \mathrm{~kg}$ eq $\mathrm{CO} 2 / \mathrm{ha} /$ year for the plot 552), with a mean of $1860 \mathrm{~kg}$ eq $\mathrm{CO} 2 /$ ha/year.

The main conclusions drawn above on the case study (plot 9) are also valid for all the fifteen plots:

- GHG emissions due to viticulture are mainly direct emissions (between 57 and $77 \%$ of the total emissions of the plot);

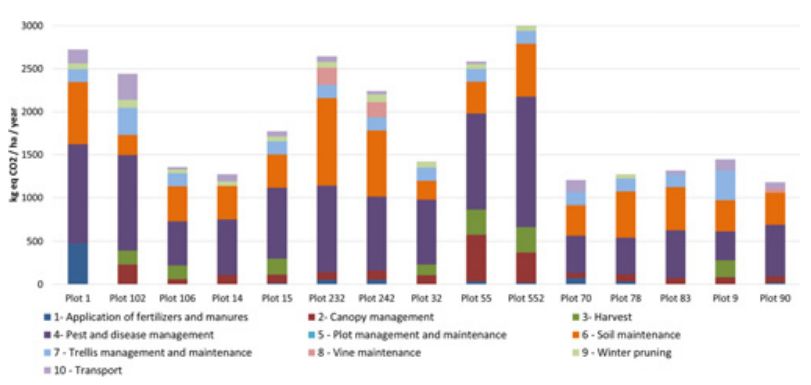

Figure 5. Results of the GHG emissions assessment for the 15 plots of Saint-Emilion and each viticultural operation.

- the most emitting vineyard operations are the Soil maintenance (between $23 \%$ and $53 \%$ of the total emissions of each plot) and the Pest and disease management (between $10 \%$ and $38 \%$ of the total emissions of each plot);

- the harvest can be a significant part of the total emissions when not manual (between $7 \%$ and $14 \%$ of the total emissions of each plot).

According to the technical itineraries, the Application of fertilizers and manures, and the Canopy management, can also constitute a significant part of the total emissions.

The variability of those results can be explained by the number of intervention days per vineyard operation, but also by the motor power of the motorized tools.

For example, the plots 55 and 552 have the same motor power for the tractor used for Pest and disease management $(150 \mathrm{hp})$, but the plot 55 have less intervention days than the plot 552 for this vineyard operation (respectively 11 and 16 days), hence the difference of $400 \mathrm{~kg}$ eq $\mathrm{CO} 2 / \mathrm{ha} /$ year between the two plots.

Then the plots 55 and 106 have the same number of intervention days for Pest and disease management, but the motor power of the motorized tool used for spraying pesticides is from single to double (150 for the plot 55, 65 for the plot 106, as the harvesting machine is used on the plot 55 for this intervention), hence the difference of $600 \mathrm{~kg}$ eq CO2/ha/year.

\section{Discussion}

It should be noted that these initial results do not yet take into account the $\mathrm{N}_{2} \mathrm{O}$ emissions linked to the application of fertilizers and manures, which are nevertheless a GHG with a high GWP (see Table 1).

However, compared to the results obtained via the AGRIBALYSE ${ }^{\circledast}$ database for the reference "Beaujolais sud, integrated management in PDO", for the reference period 2005-2009 (about $1200 \mathrm{~kg} \mathrm{CO}$ eq/ha) [2], the results obtained here are well above.

On the other hand, no soil maintenance or disease management practice clearly stands out as being less GHG-emitting. In fact, the results depend very much on the vineyard equipment (tractor power) and on the plot configuration (factors such as slope or planting density can have a strong impact on working time). Note, however, that the sample was not created to meet this objective. 


\section{Conclusion}

Direct emissions represent an important part of total emissions for each plot (between 55 and 77\%).

The most emitting vineyard operations are: pest and disease management and soil maintenance. These are two operations for which the practices and trends could be modified with climate change (increase or decrease of the diseases with the increase of the average temperature and the increase of the drought, competition of the grassing with the increased drought). It would be interesting to compare the results presented here with those of disease modeling in the face of climate change.

The vintage effect is important to consider for an environmental assessment. Comparing these first results to two more years for the same plots will help estimate the interannual variability of GHG emissions.

This study shows the importance of continuing the evaluation of different current soil and disease management, to see if trends are emerging in favor of certain modalities in the context of climate change.

\section{References}

[1] G. Wernet, C. Bauer, B. Steubing, J. Reinhard, E. Moreno-Ruiz, B. Weidema, Int. J. LCA, 21 (2016)

[2] P. Koch, T. Salou, et al., Agribalyse ${ }^{\oplus}$ : rapport méthodologique (2016)

[3] O. Jolliet, M. Margni, R. Charles, et al., Int. J. LCA 8, 324 (2003)

[4] M. Goedkoop, R. Heijungs, M. Huijbregts, A. De Schryver, J. Struijs, R. Van Zelm, ReCiPe 2008 (2009)

[5] D. Qin, G.-K. Plattner, M. Tignor, S.K. Allen, J. Boschung, A. Nauels, Y. Xia, V. Bex, P.M. Midgley, IPCC, 2013: Climate Change 2013: The Physical Science Basis. Contribution of Working Group I to the Fifth Assessment Report of the Intergovernmental Panel on Climate Change (Cambridge University Press, Cambridge, United Kingdom and New York, NY, USA, 2013), p. 1535 